\title{
The Representation of Malay Leader in Malay Song Datuk Laksemana
}

\author{
Essy Syam ${ }^{1 *}$, Ulul Azmi ${ }^{1}$, Qori Islami Aris ${ }^{1}$
}

${ }^{1}$ Faculty of Humanities, Lancang Kuning University, Pekanbaru - Riau, INDONESIA

*Corresponding Author

DOI: https://doi.org/10.30880/jstard.2020.02.03.016

Received 30 September 2020; Accepted 30 November 2020; Available online 31 December 2020

\begin{abstract}
This writing analyzes a lyric of Malay song entitled Datuk Laksemana by focusing on how a Malay leader is represented. This is a descriptive analysis which describes the phenomenon of the representations of Malay leader in that lyric. The result shows that the Malay leader is mostly represented with positive representation. Anyway there is also less positive representation which is caused by the perception believed in the era of Malay kingdoms.
\end{abstract}

Keywords: Representation, Malay, leader, lyric, Malay song

\section{Introduction}

A lyric of a song is written to be enjoyed by its listeners and to entertain the listeners. Anyway, a lyric of a song is not only written for that purpose. It is written to convey a message. A message inserted in the lyric aimed to influence the listeners. The influence can be positive or negative depends on the message itself. A lyric found in a certain society reflects certain society. It is possible because a lyric of a song, just like other artistic work, reflects the condition and identity certain culture and society. Thus, analyzing a lyric from certain society and culture will inform us about those culture and society. Analyzing a lyric of a malay song, for example, will inform us about Malay culture, society and identity. Analysis about lyric of Malay song is not widely done. There are more frequently found analysis of pop songs. There are still small numbers of analysis dealing with Malay songs, particularly lyric from Malaysia, while lyrics from Riau Malay is widely analyzed yet. Motivated by this condition, this writing will analyze a Malay lyric entitled "Datuk Laksemana." and the focus of the analysis will highlight the Malay leader. So, this writing will explore how Malay leader is represented in that lyric.

The problem discussed in this writing is to analyze how the lyric Datuk Laksemana represents Malay leader. This is an interesting analysis since a topic about Malay leader is not discussed too much, moreover when it is reflected in a lyric of a well-known song in Malay society.

\section{Theoretical Framework}

Analysis dealing with Malay lyric is quite hard to find. There are some analysis found discussing about pop songs or Malay lyric from Malaysia, while Riau Malay lyric is rarely found. Some related analysis are found such as "Perenggu Minda Melayu Dalam Lirik Lagu: Satu Analisis Makna, written by MM Daud from Universiti Kebangsaan Malaya in 2017. This analysis focuses on the meaning in the lyric to uncover malay's mind. (http://www.google.com/search?safe=strict\&source=hp\&ei=N5SUW83sDpKYvQSG8YLoBw\&q=jurnal+analisis+lirik +lagu+melayu). Other related analysis is an analysis entitled "Representasi Pemimpin Perempuan Melayu Yang tergambar Dalam Lirik Lagu melayu "Putri Tujuh" written by Essy Syam. This analysis shows that Malay woman who is represented as powerful turns out to be weak for her shortcomings causes fatal loss. The next related analysis is ana analysis entitled "Tinjauan Dekonstruktif Lagu Putri Tujuh" written by Essy Syam. This analysis concludes that lyric "Putri Tujuh" deconstructively presents unparallel ideas. In one side it shows its support to the woman leader but in 
other side it says something differently. So, from the search, it is found out that an analysis about the lyric of Datuk Laksemana is not found yet. Thus, this analysis is significant as reference for those who are interested to deal with this lyric.

\section{Lyric and Popular Culture}

Analyzing popular culture covers a wide analysis which deal with topics considered trivial but contributes a lot to human. Lyric of songs are the products of popular culture which are enjoyed in relaxation. These popular cultures have conquered the world since the beginning of the $20^{\text {th }}$ century so that the popular products have been created massively.

As the product of popular culture, a lyric can be used as effective tool to convey a message. In this case, media not only gives significant influence in conveying the message but is also able to change someone's way of thinking or even brainwash someone or group of people. This is possible because when someone is enjoying the product of popular culture, like a lyric, he/she is not in serious and critical condition in responding the lyric since he/she considers the activity is a spare time to enjoy and relax, so certain message or ideology is easily accepted without serious opposition. It shows that the products of popular culture can easily be accepted in the society because it is simple, it is a tool to get rid of tense and fatigue in life.

A message inserted in a lyric is a construction. The construction of a message is a social and interpretative activities as well as its reception. The receptions of the people from different social, economic and cultural background, create gap from various groups between productive aspects and the reception processes, between the interpretation of the message creators and those of the receptors which may cause distortion.

The signifying process in interpreting a text is signifying circulation. The message put by the encoder as part of the structured text and in the process of decoding the interpretation is not always parallel and correspondent with the interpretation of the encoder because in the process of interpretation there is always an open room for resistance since meaning is also determined by its readers 'social context. Thus, a message is not transferred instead, it is decoded. (Storey, 1996:9)

Stuart Hall classifies 3 text reading among others: dominated reader, negotiated reader and oppositional reader. The first reader's position, dominated reader is the position of readers who easily accept the message in the text. In this case, the readers accept the text as meant by the writer. That's why the readers are dominated by the text s/he reads. A bit different, Negotiated reader interprets the text more critically. This reader accepts the dominant code, but adapt it based on his/ her social condition. In this case, the reader doesn't easily accept a message instead questioning the truth critically before accepting it. Oppositional reader radically opposes the message encoded in a text because signifying system is very different. In this case, the reader should have enough knowledge in his/ her argument so the opposition can be argued convincingly. (Storey, 1996:12-13)

\section{Representation}

Representation is understood as processes in presenting something. This process is signifying process. In presenting something the signifying practice provides images which creates realistic effect from that representation. (2004:177) that's why a representation can be very convincing so that a representation is considered truth.

Just like two sides of coin, a representation always consists of two side: representative, the person or groups who represents other person or group and in other side, the represented, someone or a group who is represented by the representative.

Basically, the theory of representation provides the relation of these two groups (representative and represented), in which in the relation of these two, the representative having power to represent represented with his/her perception without the consent of the represented. This is urged by Gracia in Syam, who argues that "representation may be defined mostly as a relation between two persons the representative and the represented or constituent, with the representative holding the authority to perform various actions that incorporate the agreement of the represented."(2013:4))

So, representation not only presents something naive and trivial but also constructs a culture. A representation presented may have purpose opposing what it presents. In this case intrinsically, representation relates with power through selection process as part of creating the representation.

When we talk about representation from different groups for example, we are questioning the meaning of a black man, for instance, with the politic of representation, a black man does not reflect the essence of black itself, instead reflecting an identity which has been represented and believed as a black man with labels attached to him (usually negative). So, the politic of representation deals with power relation contains in the representation "black" which in the same time deconstructs the binary positions of black and white (2004:177). It shows that representation has strong relation with power.

A culturalist, Christopher Prendergast also argues the concept of representation. For him, representation comes from the word re-present which means "to make present again," or to exist again either with related way or partially or temporarily. (2009:8). Prendergast states that something presents here refers to something which is not there, but is considered to be there. From this condition, it indicates that representation has ability to present something so that it is 
seen. Besides, Prendergast also offers an idea the presence which is represented or substituting something to present something or someone or someone else. In this case, language becomes concrete. When someone says "cat", for example, the concept of cat exists brought by consciousness which is represented by that animal, even though no cat exists there. (2009:10)

Moreover, Stuart Hall in Webb also defines representation as the constructing meaning through language. Furthermore, Hall argues that representation is "the production of the meaning of the concepts in our minds through language."(2009:10). So, representation is the meaning construction through the medium of language to depict something based on someone's perception or the representative's perception.

In discussing about this idea, Constructionist approach is the appropriate approach in explaining it. Constructionist approach urges that social doer is the figure who constructs the meaning because social doer uses the concept system from his/her culture. (Hall, 1997: 24-25). This approach provides complex relation because word used in language contains representation which is the code in language, in more widely sense, to whole discourses which operate through various texts which put representation as the source of "the production of social knowledge," (Hall, 1997:42). Representation highlights various social practices which imply the power relation.

Besides, W. Said also discusses about representation by expressing the condition which shows how the West considers that the East is unable to represent itself, so with that excuse the West takes over the role to represent the east. The Representation done by the West towards the east creates the image (stereotype) attached to the east as the represented as afford to label. This labeling aims to weaken the represented and in the same time strengthening the representative.

\section{Methodology}

This analysis applies descriptive approach which describes a phenomenon exists in the text. Descriptive approach aims to accurately and systematically describe the characteristics of the phenomenon to answer and to understand it. In this case, it describes the representations of Malay leader reflected in a lyric of Malay song entitled "Datuk Laksemana".

\section{Discussion}

The analysis shows that the lyric Datuk Laksemana represents Malay leader who is wise, the leader who works for his people, the one who controls the sea and the leader who has superstitious power.

\section{Wise Leader}

Implicitly, this lyric expresses the life of Malay society which expects a leader who has main criterion that is wisdom. This criterion is very important because wise attitude should be possessed by a leader. Malay people put this criterion in priority that's why the word bijak (wise) is repeated several times in the lyric. Datuk Laksemana bijak bestari, this sentence is found in the first line as the opening of the song and is repeated in in the $19^{\text {th }}$ line. So, implicitly this lyric says that someone who has no wisdom doesn't deserve to be a leader. A leader's wisdom is needed in order the decision made doesn't tyrannize and cause harm to the people. Then, that wisdom will create peace in the society.

By prioritizing wisdom as important criterion for a leader, Malay society realizes the big role of a leader in managing the life of the people. This criterion is not only expected by Malay people since anywhere a leader is expected to act wisely in doing his/ her role as leader. The representation of Malay leader who is wise in this lyric shows the respect and appreciation toward a leader. By representing a wise leader, it creates a positive image. In this case, the Malay people show that they are the people with dignity because having wise leader, the people or the society should be dignified and thus deserved to be respected. So, this positive representation aims to strengthen the dignity of Malay people.

\section{Working Leader}

Ideally, a leader works for his/her people. A good leader should keep questioning and thinking what should be given to the people. This lyric Datuk Laksemana shows that by expressing that a leader holds big responsibility which makes him/her keep thinking the people s/he leads in any circumstances, whether when s/he is sitting, or standing. It is implied from the second line of the lyric which says duduk menyirat, tegak mencari. This sentence says that a leader keeps thinking about his/her people. When s/he is sitting, he is thinking and when he is standing, he is also thinking to get solution to problems faced by his/her people. To strengthen this, the sentence is repeated in the $20^{\text {th }}$ line.

The representation of a leader who works for his/her people is also a positive representation which indicates good value held by the Malay people. This lyric argues that a leader is not the person who command other to do something, instead $\mathrm{s} / \mathrm{he}$ is the one who should do something or the one who should work for the people. So, becoming a leader is not a chance to have fun or to be respected by others, but it is a hard and serious responsibility. By so, this lyric tries to say that Malay leader understands the responsibility s/he holds so that s/he will feel ashamed if s/he doesn't fulfill the 
responsibility and s/he will feel that s/he doesn't deserve the position when s/he ignores his/her duty. So. Once again, this lyric strengthns the positive image of the Malay people who aware of his/her duty and responsibility.

\title{
Leader with Supernatural Power
}

Datuk Laksemana is represented as a leader who has supernatural power, in which he has magical power. With this power is can easily catches Terubuk fish only by dipping his legs in Tanjung Jati (Jati cape). When he dips his legs Te th rubuk fish will come to him by themselves. In this case, Datuk Laksemana has supernatural power in which he can control living creature like fish to come to him so he can catch them easily. This can be seen in the $3^{\text {rd }}$ to $6^{\text {th }}$ line of the lyric.

\author{
Tersebut kisah Datuk Laksemana \\ Di Tanjung Jati celupkan kaki \\ Ikan terubuk datang hampiri \\ Tuah diberi semula jadi
}

This lyric explains his power and at the end of the lyric it informs that the supernatural or the magical power Datuk Laksemana has is obtained naturally. The sentence Tuah diberi semula jadi strengthens that. It indicates that a Malay leader inherits the supernatural power so it is not necessary for him to obtain that power because it is there with him automatically. So, the leader only needs to make good use of the power he has. To stress on it, the lyric also repeats the sentence in the $21^{\text {th }}$ to $24^{\text {th }}$ lines. With this supernatural power, Datuk Laksemana is represented as powerful person which leads to a belief that with that power he is a true hero by describing him as satria sejati, which is explicitly stated in the $11^{\text {th }}$. So, having supernatural power is identified with magical, which is considered common and is taken for granted to be owned by a leader in Malay society.

The representation of Malay leader with his supernatural power, in one side, is considered common and appropriate possessed by a Malay leader. On the other side, it creates less positive image because having supernatural power is not recommended in Islam as the religion embraced by Malay people. A belief which believes that having supernatural power is bless to increase good value for a leader, is a belief influenced by Hinduism. It is possible that the lyric is written to describe Malay society in the era when Malay society was led by kingdoms where the kings having that magical power.

\section{Leader who Controls the Sea}

Datuk Laksemana is represented as the sea controller which implicitly he is a great sailor. As the controller of the sea, Datuk Laksemana is represented as a hero or a knight who enthroned in Bukit Batu. So, Datuk Laksemana conquers Tanjung Jati which brings Tanjung Jati under his control and it is described in $7^{\text {th }}$ to $10^{\text {th }}$ lines.

\author{
Tersebut Datuk Laksemana \\ Satria Raje di laut \\ Datuk Laksemana Raje di laut \\ Di Bukit Batu tempat tahtanya.
}

Like other repeated lines, this line is also repeated in the $13^{\text {th }}$ to 16 lines to stress on the meaning and the message. The representation of a Malay leader who controls the sea is a positive representation because the representation implies the skill and power possessed by a leader. To control the sea is not an easy thing to do. Someone needs to have adequate skill and knowledge to detect the condition of the sea. With those skill and knowledge the person can decide when to sail safely and how to save himself when the sea is not in good condition. He should also be able to predict the big or small waves and he can overcome the situation appropriately, he understands the life surround the sea in the maritime country. So, the representation of a leader who controls the sea shows good quality of a leader who understands his nature environment condition and with this understanding he can decide certain problem correctly and overcome a problem well.

Laksemana is represented as a leader who has supernatural power, in which he has magical power. With this power, it is can easily catches Terubuk fish only by dipping his legs in Tanjung Jati.

\section{Conclusion}

From the analysis, it can be concluded that the lyric Datuk Laksemana represents Malay leader with positive representations such as representing him as wise leader, leader who works for his people and leader who controls the sea. These representations create positive significations to strengthen the positive quality possessed by a Malay leader. Besides, this lyric also represents a Malay leader of having supernatural or magical. This representation is not parallel with Malay people who are identical with Islam since Islamic teaching doesn't recommend its follower to have such kind of power. This representation creates less positive signification. Anyway it is considered accepted in the era when 
Malay society was led by supernatural thought when Malay kingdoms were still influenced by Hindu's doctrine and culture.

\section{Acknowledgment}

The author would like to express their gratitude to Faculty of Humanities, Lancang Kuning University, Pekanbaru, Riau for the assistance and the information provided to ensure the success of the study.

\section{References}

[1] Barker, Chris, The Dictionary of Cultural Studies, SAGE Publication, London: 2004

[2] Hall, Stuart, Representation: Cultural Representation and Sygnifying Practices, Sage Publication and Open University, London: 1997

[3] Said, Edward, Orientalism: Western Conception of the Orient, Penguin Books, New York: 1992

[4] Storey, John, An Introduction Guide to Cultural Theory and Popular Culture, Harvester Wheatleaf Great Britain: 1993

[5] Syam, Essy, Garcia's Representation dalam Sills'International Encyclopedia of the Social Sciences, Jurnal Ilmu Budaya, Fakultas Ilmu Budaya, Universitas Lancang Kuning, Pekanbaru: 2013

[6] __ Representasi pemimpin Perempuan Melayu Yang Tergambar Pada Lirik Lagu Melayu "Putri Tujuh", Jurnal Ilmu Budaya: Fakultas Ilmu Budaya, Universitas Lancang Kuning, Pekanbaru: 2019

[7] Webb, J, Understanding Representation, SAGE Publication, Ltd, London: 2009 